УДК 340.12

\author{
Катерина Валеріївна Николина, \\ кандидат юридичних наук, доиент кафедри \\ теорії права та держави Київського національного \\ університету імені Тараса Шевченка
}

\title{
ПРОЦЕДУРНІ ОСОБЛИВОСТІ ПРАВОВОГО МОНІТОРИНГУ ТЕКСТУАЛЬНОГО ВИРАЗУ ПРАВА: ПРАГМАТИЧНИЙ ПІДХІД
}

Постановка проблеми. Нормативна інституалізація та захист прав людини, практичне втілення верховенства права в світлі євроінтеграційних процесів є пріоритетом розвитку вітчизняної правової системи. Слід наголосити, що не дивлячись на доволі прогресивні конституційні положення, наявність великого масиву законодавства, в цій сфері на сьогодні існує ряд проблем. Зокрема, істотними є недоліки юридичної техніки творення нормативно-правових актів, відсутність чіткого правового регулювання окремих фактично існуючих суспільних відносин, недосконалість застосування та офіційного тлумачення норм права, що ставить під сумнів ефективність правового регулювання в цілому. Виконання Україною взятих на себе зобов'язань відповідно до Угоди про асоціацію між Україною, з однієї сторони, та Європейським Союзом і його державами-членами, з іншої сторони, від 16 вересня 2014 р. щодо уніфікації та гармонізації національного законодавства і приведення його у відповідність 3 міжнародними стандартами передбачає наявність прозорих та дієвих інструментів правового моніторингу.

Моніторинг законопроектів, чинного законодавства та практики його застосування повинен виступати одним із важливих інформаційно-аналітичних компонентів формування правової політики держави. Інструментарій, яким оперує правовий моніторинг, дозволяє виявити можливі корупційні ризики того чи іншого нормативного акту, критично оцінити його з точки зору порушення гендерних прав, інших видів дискримінації; віднайти та проаналізувати колізії та прогалини в правовому регулюванні.

Аналіз останніх досліджень і публікацій. У вітчизняній юридичній науці доктрина правового моніторингу знаходиться на етапі становлення, що має наслідком відсутність єдиної методології та техніки проведення моніторингу. Проте варто відзначити підвищений інтерес до цієї тематики на сучасному етапі з боку українських науковців. Зокрема, деякі питання правового моніторингу висвітлені в роботах О. Богачової, Ю. Градової, О. Копиленка, Н. Нижник, М. Петришиної, І. Шутака, I. Онищука та ін.

Теоретична розробка питань правового моніторингу більш детально здійснена зарубіжними авторами, зокрема в працях А. Н. Алексєєва, Ю. Г. Арзамасова, Д. Б. Горохова, О. В. Дамаскіна, Л. О. Іванової, І. В. Жужгова, Л. А. Кравченка, Я. С. Наконечного, Ю. А. Тихомирова, Н. Н. Толмачової, А. С. Фадєєвої тощо. Крім цього, система правового моніторингу врегульована також на нормативному рівні в таких країнах, як Болгарія, Хорватія, Сербія, Румунія, Естонія, Білорусь, Казахстан та ін.

Правовий моніторинг як дієвий інструмент контролю наразі використовується в різноманітних юридичних сферах, про що свідчить видання відповідних посібників стосовно моніторингу незалежності суддів, дотримання прав людини, моніторингу діяльності місцевих депутатів тощо.

Аналіз сучасних досліджень моніторингу в сфері права дозволяє констатувати відсутність єдиного офіційно сприйнятого термінологічного апарату, невизначеність юридичної процедури здійснення моніторингу, неоднозначність розуміння об'єктів та суб'єктів такої діяльності.

Мета статті. Враховуючи значні теоретичні прогалини в сфері організації і проведення правового моніторингу, в межах даної статті пропонується встановити процедурні особливості правового моніторингу як юридичної діяльності.

Основні результати дослідження. Різноманітність сфер використання моніторингу обумовлює термінологічний плюралізм у його розумінні. Так, в літературі в контексті правового моніторингу в якості синонімів вживаються такі категорії, як «моніторинг законодавства», «моніторинг право- 
застосування», «моніторинг нормативно-правових актів», «моніторинг правової системи» та ін. При цьому змістовно ці поняття покликані позначити оцінку якості та ефективності правового регулювання, а також його практичної реалізації в межах правозастосування. На нашу думку, проблема полягає в тому, що вказані категорії позначають окремі види правового моніторингу, який виступає родовим поняттям. Істотне значення має також розмежування термінів «правовий моніторинг» та «моніторинг права», однак в межах цієї статті не будемо акцентувати на ньому увагу.

Ю. А. Тихомиров визначає правовий моніторинг «як динамічний організаційний і правовий інститут інформаційно-оціночного характеру, що рухається по всім стадіям функціонування управління, господарювання тощо і проявляється на всіх етапах виникнення та дії права» [1, с. 13]. Таке визначення дозволяє говорити про правовий моніторинг в широкому розумінні як про узагальнюючу категорію. Але, на нашу думку, в цьому випадку не відображено конкретні цілі здійснення моніторингу, що не дозволяє в повній мірі з’ясувати сутність цього процесу.

На думку I. І. Онищука правовий моніторинг - це інноваційний прагматичний метод отримання знання про якість та ефективність НПА; самостійний, спеціальний вид правового контролю, що поєднує інформаційний (демонстраційний), аналітичний, інтерпретаційний, експертний, прогнозний, систематичний супровід правотворчості й правозастосування; періодичне (постійне) стеження за динамікою й статикою правових відносин і норм, за взаємозв'язком формалізованої правотворчості та правозастосування [2, с. 65]. Надаючи таке комплексне визначення, автор очевидно намагається відобразити всю багатоманітність прояву моніторингу в сфері права. Однак, на нашу думку, такий підхід $є$ не зовсім вдалим, оскільки ускладнює формування однозначного та усталеного уявлення про процедуру, об’єкт та суб'єктів моніторингу для потреб практики. Характеристика правового моніторингу як методу виключає необхідність його законодавчого регулювання. Визначення правового моніторингу в якості спеціального виду правового контролю потребує додаткового роз'яснення терміна «правовий контроль», який майже не вживається в юридичній науці. Окрім цього, вважаємо що конструкція «періодичне (постійне) стеження» як альтернатива терміна «моніторинг» не відображає ані зміст, ані сутність досліджуваного явища в праві.

Цікавим є той факт, що в західній юриспруденції відсутній термін «правовий моніторинг», а також окремі закони, які б регулювали процедуру його проведення. Як правило, мова іде про аналіз ефективності та якості національного законодавства. Крім цього, існують спеціальні неурядові організації, які здійснюють моніторингову діяльність, уповноважені розробляти відповідні стандарти та техніку проведення. Метою моніторингу в сфері права в західних суспільствах, як правило, є виявлення порушень прав людини або недотримання верховенства права як на рівні законодавства, так і в процесі правозастосування.

Націленість правового моніторингу на виявлення та формування варіантів вирішення існуючих в правовій сфері проблем дає підстави досліджувати його із застосуванням прагматичного підходу. Як влучно зазначає Є. В. Атрашкевич в своєму дисертаційному дослідженні, обгрунтовуючи необхідність використання зарубіжного досвіду філософсько-правового осмислення правової реальності: «прагматизм більшою мірою зорієнтований на реальне правове життя, ніж на політичні та правові теорії, що зумовлює практичну необхідність вирівняти дисбаланс між правовою реальністю і формами їі осмислення» [3, с. 1].

Класичне правило прагматизму, яке було сформульоване ще у 1878 році Ч. Пірсом в праці «Як зробити наші ідеї ясними», являє собою «правило досягнення третього (найвищого) ступеня ясності»: розгляньмо, які наслідки, що гіпотетично могли б мати практичне значення, має об'єкт нашого поняття; у такому разі наше поняття щодо цих наслідків складає всю повноту нашого поняття щодо об'єкта» [4, с. 270]. Отже, прагматичний підхід дозволяє визначати правовий моніторинг як цілеспрямовану діяльність, що передбачає досягнення конкретних результатів, які мають практичне значення для вдосконалення правового регулювання та правозастосування.

Відповідно до концепції сучасної представниці неопрагматизму С. Хаак, інституціоналізація права як сфери адекватного знання про контексти життєвого простору, за концепцією, неможлива без підтримки правових процедур та рішень, збагачених ознаками науковості у формі формально-логічних та раціоналізованих алгоритмів розв'язання правових проблем і прийняття правових рішень [3, с. 13]. В цьому зв'язку нам видається необхідним встановити процедурні ознаки правового моніторингу.

Звертаючись до Великого тлумачного словника сучасної української мови, знаходимо визначення моніторингу як безперервного стеження за будь-яким процесом 3 метою виявлення його 
відповідності бажаному результату [5, с.538]. В іншому словнику зазначається походження слова «моніторинг» (monitoring) від англ. monitor - спостережний, і використовується це поняття у значенні постійного спостереження за якимось процесом з метою виявлення його відповідності бажаному результату чи попереднім припущенням [6, с. 287]. В англомовному юридичному термінологічному словнику Блека існує термін «monitor», який має наступні значення: відстежувати, перевіряти, контролювати або дивитися; проводити систематичну і повторювану послідовність вимірювань або спостережень щодо контрольних параметрів [7].

Таким чином, контент-аналіз терміна «моніторинг» свідчить про процедурний характер відповідної діяльності, оскільки у визначеннях наголошується на цілеспрямованих, поетапних, триваючих в часі діях. Безумовно, варто також зважати на те, що змістовне наповнення терміна буде залежати від сфери його використання.

Повернемось до теоретичного дослідження моніторингу в рамках юридичної науки. Інший варіант розуміння правового моніторингу пропонує закріпити на законодавчому рівні Ю. В. Градова. Автор визначає його як систематичну, комплексну, в межах законодавчо визначених повноважень, діяльність органів публічної влади та громадських формувань, спрямовану на спостереження, аналіз та оцінку правової системи з метою поліпшення іiі сучасного стану та прогнозування іiї подальшого розвитку [8, с. 47]. Такий підхід нам видається більш обгрунтованим, оскільки розглядає моніторинг як вид діяльності, що характеризується послідовністю етапів і має процедурний характер.

Юридична процедура існує як особлива форма легітимації та авторитетності рішень, що насамперед важливо для правових форм юридичної діяльності. В дисертаційному дослідженні та інших наукових працях ми неодноразово обгрунтовували, що юрисдикційним процесом не обмежується вся багатоманітність юридичних процедур [9]. Окрім судового вирішення юридичних спорів існують ще складні процедури правотворчості, укладання договорів, складання заповітів тощо, які неможливо уявити без дотримання певних правил.

У правознавчій літературі юридична процедура визначається як «особливий нормативно встановлений порядок здійснення юридичної діяльності, що забезпечує реалізацію норм матеріального права й матеріальних правовідносин, який охороняється від порушення правовими санкціями». 3 іншої позиції, юридична процедура являє собою «особливий нормативний порядок здійснення юридичної діяльності, тобто визначену юридичну форму, а також організуючий засіб забезпечення непримусової реалізації права» [9, с. 39-41]. Поєднуючи зазначені підходи, видно, що процедуpa, в тому числі і в правовому розумінні, визначається як особливий порядок вчинення певних дій (або їх невчинення), які мають юридичне значення і наслідки, причому зазначений порядок має чітко визначену форму та зміст.

Юридичні процедури структурують правовий простір та характеризують особливий статус учасників правовідносин через визначення їх повноважень. Процедурність в юридичній діяльності має ключовий характер для її легітимності, ефективності та результативності, оскільки забезпечує виваженість та послідовність у діяльності суб'єктів юридичної діяльності.

Сферу використання юридичної процедури, на нашу думку, можливо розглядати в двох аспектах. По-перше, юридична діяльність та юридичний процес (як її форма) своїм змістом мають окремі юридичні процедури, що визначають етапи, дії в межах визначених процесуальних стадій. В цьому випадку юридична процедура має організаційний і службовий характер, оскільки виступає засобом впорядкування розвитку юридичного процесу. По-друге, юридична процедура як самостійна категорія характеризує випадки реалізації права, що не пов'язані із правозастосуванням та правотворчістю (використання, виконання, дотримання норм права, договірні відносини, початковий етап правоутворення, медіація тощо). На нашу думку, саме другий аспект характеристики юридичної процедури дозволяє проводити термінологічні паралелі з правовим моніторингом, визначаючи його як окремий вид юридичної процедури.

Враховуючи вищенаведене, правовий моніторинг можливо визначити як спеціальну діяльність, що має процедурний характер, здійснюється уповноваженими суб'єктами з метою аналізу та оцінки результатів правотворчого процесу, якості нормативно-правових актів, ефективності правозастосування, а також спостереження в динаміці за іншими правовими явищами, результатом чого $\epsilon$ вироблення пропозицій щодо їх вдосконалення та/або прогнозування подальшого розвитку.

Процедурний характер моніторингу в праві передбачає здійснення його в межах певних етапів, стадій, які в свою чергу є сукупністю чітко визначених, послідовних дій суб'єктів. Зміст цих стадій безпосередньо залежить від виду моніторингу, його об'єкта та суб'єктного складу. Наприклад, I. I. Онищук в сфері правового регулювання виокремлює такі види моніторингу: суспільних 
відносин; правового поля; правового простору; правозастосовної практики; реалізації права законодавчої ініціативи; формалізованої правотворчості; муніципальної правотворчості; корпоративний моніторинг; моніторинг договірних зобов'язань держав-членів РЄ; моніторинг виконання рішень Європейського суду з прав людини тощо [2, с. 150]. Очевидно, що засоби, способи та критерії проведення кожного з різновидів моніторингу матимуть свою специфіку.

В узагальненому ж вигляді юридичну процедуру правового моніторингу можливо відобразити у вигляді наступних стадій: підготовча (в рамках якої здійснюється вибір об’єкта, мети моніторингу; визначається коло суб'єктів, розробляється програма та критерії оцінювання); основна стадія (збір інформації про об'єкт (соціологічні, статистичні дослідження), проведення моніторингової (юридичної, наукової) експертизи; аналіз та оцінка нормативного регулювання та/або правозастосовної практики тощо); заключна стадія (узагальнення та оформлення висновків, формулювання пропозицій щодо вдосконалення об'єкта моніторингу, прогнозування напрямків його розвитку).

Віднесення правового моніторингу до різновиду юридичної процедури має важливе практичне значення, оскільки в цьому разі на нього поширюються вимоги належності юридичної процедури, що становлять собою систему універсальних базових ідей та принципів, які визначають характер і межі процедурного порядку реалізації правових приписів з метою забезпечення і захисту прав людини та дотримання загальнолюдських суспільних цінностей [10, с. 46]. В якості загальних принципів проведення правового моніторингу нами пропонується визначити: законність, демократизм, дотримання прав людини, об'єктивність та неупередженість, достовірність, професійність, диспозитивність, прозорість процедури, чіткість критеріїв оцінки та ін.

Висновки. В якості підсумку варто зазначити, що враховуючи динамічний характер правового моніторингу, йому, як і будь-якій юридичній діяльності, притаманна ознака процедурності. Відповідно на діяльність із правового моніторингу, окрім специфічних принципів, поширюються також вимоги належності юридичної процедури. Це в свою чергу виступає додатковою гарантією легітимності форм, процесу та результату моніторингу в праві.

\section{Список використаних джерел}

1. Тихомиров Ю. А. Организация и проведение правового мониторинга / Ю. А. Тихомиров // Право и економика. 2006. № 10. C.13

2. Онищук I. I. Правовий моніторинг: теоретичні та прикладні засади.: дис. ... д-ра юрид. наук : 12.00 .01 / Онищук Ігор Ігорович ; Нац. акад. внутр. справ. Київ, 2018. 554 с.

3. Атрашкевич C. В. Неокласичний прагматизм Сьюзан Хаак у сучасному англо-американському філософсько-правовому дискурсі : автореф. дис. ... канд. юрид. наук / Є. В. Атрашкевич. Одеса, 2016. 21 с.

4. Пирс Ч. С. Как сделать наши идеи ясными / Ч. С. Пирс // Пирс Ч. С. Избранные философские произведения: Пер. с англ. К. Голубович, К. Чухрукидзе, Т. Дмитриева. М. : Логос, 2000. С. 266-295.

5. Великий тлумачний словник сучасної української мови / [уклад. і голов. ред. В. Т. Бусел]. К. ;Ірпінь : ВТФ «Перун», 2001. 1440 с.

6. Загоруйко О. Я. Великий універсальний словник української мови / О. Я. Загоруйко - Х. : Торсинг Плюс, 2009. - $768 \mathrm{c}$.

7. [Електронний ресурс]. Режим доступу: https://thelawdictionary.org/monitor/

8. Градова Ю. В. Щодо необхідності розробки та прийняття Закону України «Про правовий моніторинг». Вісник Харківського національного університету імені В. Н. Каразіна. Серія «Право». 2017. Вип. 24. С. 46-48.

9. Николина К. В. Юридична процедура: поняття, ознаки, види, місце в системі правових категорій : дис. ... канд. юрид. наук : 12.00 .01 / К. В. Николина ; Нац. пед. ун-т ім. М. П. Драгоманова. К., 2011. 215 с.

10. Николина К. В. Належна юридична процедура: теоретичні аспекти визначення / К. Николина // Вісник Київського національного університету імені Тараса Шевченка. Юридичні науки. 2012. Вип. 94. С. 44-46 [Електронний ресурс] Режим доступу : http://nbuv.gov.ua/UJRN/VKNU_Yur_2012_94_13

\section{References}

1. Tihomirov Ju. A. Organizacija i provedenie pravovogo monitoringa / Ju. A. Tihomirov // Pravo i ekonomika. 2006. \# 10. S. 13

2. Onyshhuk I. I. Pravovyj monitoryngh: teoretychni ta prykladni zasady.: dys. ... d-ra juryd. nauk : 12.00 .01 / Onyshhuk Ighor Ighorovych ; Nac. akad. vnutr. sprav. Kyjiv, 2018. $554 \mathrm{s.}$

3. Atrashkevych Je. V. Neoklasychnyj praghmatyzm Sjjuzan Khaak u suchasnomu anghlo-amerykansjkomu filosofsjkopravovomu dyskursi : avtoref. dys ... kand. juryd. nauk / Je. V. Atrashkevych. Odesa, 2016. $21 \mathrm{~s}$.

4. Pirs Ch. S. Kak sdelat' nashi idei jasnymi / Ch. S. Pirs // Pirs Ch. S. Izbrannye filosofskie proizvedenija: Per. s angl. K. Golubovich, K. Chuhrukidze, T. Dmitrieva. M. : Logos, 2000. S. 266-295. 
5. Velykyj tlumachnyj slovnyk suchasnoji ukrajinsjkoji movy / [uklad. i gholov. red. V. T. Busel]. K. ; Irpinj : VTF «Perun», 2001. $1440 \mathrm{~s}$.

6. Zaghorujko O. Ja. Velykyj universaljnyj slovnyk ukrajinsjkoji movy / O. Ja. Zaghorujko - Kh. : Torsyngh Pljus, 2009. $-768 \mathrm{~s}$.

7. [Elektronnyj resurs]. Rezhym dostupu : https://thelawdictionary.org/monitor/

8. Ghradova Ju.V. Shhodo neobkhidnosti rozrobky ta pryjnjattja Zakonu Ukrajiny «Pro pravovyj monitoryngh». Visnyk Kharkivsjkogho nacionaljnogho universytetu imeni V. N. Karazina. Serija «Pravo». 2017. Vyp. 24. S. 46-48.

9. Nykolyna K. V. Jurydychna procedura: ponjattja, oznaky, vydy, misce v systemi pravovykh kateghorij : dys. ... kand. juryd. nauk : 12.00.01 / K. V. Nykolyna ; Nac. ped. un-t im. M. P. Draghomanova. K., 2011. 215 s.

10. Nykolyna K. V. Nalezhna jurydychna procedura: teoretychni aspekty vyznachennja / K. Nykolyna // Visnyk Kyjivsjkogho nacionaljnogho universytetu imeni Tarasa Shevchenka. Jurydychni nauky. 2012. Vyp. 94. S. 44-46. [Elektronnyj resurs]. Rezhym dostupu : http://nbuv.gov.ua/UJRN/VKNU_Yur_2012_94_13

\section{Николина К. В. Процедурні особливості правового моніторингу текстуального виразу права: прагматичний аспект}

У статті обгрунтовується процедурний характер правового моніторингу на основі використання прагматичного підходу. Аналіз сучасних досліджень моніторингу в сфері права дозволяє констатувати відсутність єдиного офіційно сприйнятого термінологічного апарату, невизначеність юридичної процедури здійснення моніторингу, неоднозначність розуміння об'єктів та суб'єктів такої діяльності. Прагматичний підхід дозволяє визначати правовий моніторинг як цілеспрямовану діяльність, що передбачає досягнення конкретних результатів, які мають практичне значення для вдосконалення правового регулювання та правозастосування.

Автором доводиться процедурний характер моніторингу в праві, що обумовлює поширення на нього, окрім спеціальних принципів, вимог до належної юридичної процедури. В узагальненому вигляді юридичну процедуру правового моніторингу можливо відобразити у вигляді наступних стадій: підготовча (в рамках якої здійснюється вибір об'єкта, мети моніторингу; визначається коло суб'єктів, розробляється програма та критерії оцінювання); основна стадія (збір інформації про об'єкт (соціологічні, статистичні дослідження), проведення моніторингової (юридичної, наукової) експертизи; аналіз та оцінка нормативного регулювання та/або правозастосовної практики тощо); заключна стадія (узагальнення та оформлення висновків, формулювання пропозицій щодо вдосконалення об'єкта моніторингу, прогнозування напрямків його розвитку).

Ключові слова: правовий моніторинг, процедурність, юридична діяльність, юридична процедура, правова експертиза, прагматизм, належна процедура.

\section{Nykolyna K. V. Procedural features of legal monitoring of the textual expression of law: the pragmatic aspect}

The article substantiates the procedural nature of legal monitoring based on the use of a pragmatic approach. Monitoring of bills, current legislation and practice of its application should act as one of the important information-analytical components of formation of the legal policy of the state.

The analysis of modern research in the field of monitoring allows one to state the absence of a single officially perceived terminology apparatus, the uncertainty of the legal procedure for monitoring, ambiguity in understanding the objects and entities of such activities. The objective of legal monitoring to identify and formulate solutions to existing problems in the legal field provides grounds for investigating it using a pragmatic approach. The pragmatic approach allows one to define legal monitoring as a targeted activity, which involves achieving concrete results that are of practical importance for the improvement of legal regulation and enforcement.

In the generalized form, the legal procedure for legal monitoring may be reflected in the following stages: preparatory (within the framework of which the choice of the object, the purpose of the monitoring is carried out, the range of subjects is determined, the program and the criteria of evaluation are developed); main stage (collection of information about the object (sociological, statistical research), monitoring (legal, scientific) examination; analysis and assessment of normative regulation and / or enforcement practice, etc.); the final stage (generalization and drawing up of conclusions, formulating proposals for improvement of the monitoring object, forecasting directions of its development).

Taking into account the above, legal monitoring may be defined as a special activity of a procedural nature carried out by authorized agents for the purpose of analysis and evaluation of the results of the law-making process, the quality of normative legal acts, the effectiveness of enforcement, as well as the observation in the dynamics of other legal phenomena, the result what is the development of proposals for their improvement and / or forecasting of further development. As a general principle of legal monitoring, we are asked to determine: legality, democracy, respect for human rights, objectivity and impartiality, reliability, professionalism, discretion, transparency of procedure, clarity of evaluation criteria, etc.

The assignment of legal monitoring to a type of legal procedure is of great practical importance, since in this case it is subject to the requirements of due procedure.

Key words: legal monitoring, procedural, legal activity, legal procedure, legal expertise, pragmatism, due procedure.

DOI: 10.33.66.3/2524-017X-2019-10-198-202 